\title{
Entre os corpos das ruínas
}

Jacqueline Ceballos Galvis

IEL-UNICAMP

\section{Resumo}

A escrita de Boris Pahor está impregnada pelas marcas da catástrofe. Mais de uma língua deixa passar corpos famintos, maltratados, feridos, usados, abusados, gaseados, queimados, violentados, esquartejados; corpos humanos, animais, vegetais, inclusive anticorpos, doenças, vírus, que não deixaram de ser transpassados pela guerra. Esse transbordamento do sofrimento, da exposição e da experimentação dos corpos vibra a carne viva entre os signos do testemunho, e se mostra como uma das monstruosidades mais terríveis cometidas na história. Nesse sentido, tenta-se questionar o controle sobre o corpo que se encontra no cerne das práticas do regime nazifascista, assim como essa articulação entre domínio e luta, que não tem deixado de emitir signos e fissuras entre a literatura e o pensamento nos diferentes âmbitos da cotidianidade.

Palavras-chave: Testemunho; corpo; guerra; catástrofe; ruínas.

\section{Resumen}

La escritura de Boris Pahor está impregnada por las marcas de la catástrofe. A más de una lengua deja pasar por cuerpos hambrientos, maltratados, heridos, usados, abusados, gaseados, quemados, violados, descuartizados; cuerpos humanos, animales, vegetales e incluso anticuerpos, enfermedades, virus, que no dejaron de ser traspasados por la guerra. Ese sufrimiento desbordado, la exposición y la experimentación de los cuerpos vibran en carne viva entre los signos del testimonio, mostrándose como una de las monstruosidades más terribles cometidas en la historia. En ese sentido, se intenta cuestionar el control sobre el cuerpo, que se encuentra en el centro de las prácticas del régimen nazi-fascista, así como la articulación entre dominio y lucha, que no ha dejado de emitir signos y fisuras entre la literatura y el pensamiento, en los diferentes ámbitos de la cotidianidad.

Palabras-clave: Testimonio; cuerpo; guerra; catástrofe; ruinas. 
1. STIVELMANN, Michael \& Raquel. A marca dos genocídios, 2001, p. 272.

2. Como sobrevivente judeu de nacionalidade lituano-francesa foi vítima da catástrofe e teve que suportar o espinho no coração pelo desaparecimento de muitos familiares. E vale lembrar que não apenas aqueles textos em que o pensamento marcado pelo caráter ético não cessa de responder ao desastre de tantos assassinados pela mesma expressão soberba da totalidade, mas também seus Carnets escritos nos anos de cativeiro de 1940 até 1945.
Em Necrópole, relato autobiográfico e testemunhal de Boris Pahor, a língua singular plural do testemunho se oferece, se passa, se expõe ao grito sobrevivente do corpo. Na corporeidade despedaçada de uma linguagem exiliada, sem inimistar-se com a luz nem com as sombras, o escritor é tomado, se aventura nessas memórias dolosas, corporais, orgânicas, espaciais e não só temporais. Arrisca-se no que não se deixa calar, no abismo incrustado nas entranhas. $\mathrm{Na}$ noite inelutável que se manifesta no olhar nu daqueles que se foram para não voltar, e nessa infinita finitude não cessam de revoltar, de perturbar, de arruinar as melhores vontades conciliatórias, rebeldes às sínteses reconciliatórias.

O controle sobre o corpo se encontra no cerne das práticas do regime nazifascista. Uma das primeiras medidas a partir de 1933 foi a esterilização dos grupos minoritários no combate à miscigenação com judeus, negros, ciganos, entre outros chamados de "moralmente inferiores", "cabendo só ao Reich definir os critérios de moralidade social e reprimir a prática à miscigenação, fatal para a pureza da raça ariana"1. Já em 1934, momento de auge nacionalista, E. Levinas ${ }^{2}$, à contramão das crescentes complacências idolátricas e ciente de que o pensamento não pode ignorar as feridas e as emergências do tempo, escrevia Algumas reflexões sobre a filosofia do bitlerianismo, por meio das quais argumenta sérias questões que permitem pensar a respeito da "limpeza racial" e das políticas próprias da germanização em marcha, cuja obstinação pela suposta pureza remarca o jargão da autenticidade que lembra Adorno, se cristalizaram perversamente no extremo limite dos fornos. Herdeiro do cruzamento entre tradições e sob a inspiração de pensadores como Franz Rosenzweig, Husserl, Heidegger, entre outros, Levinas evoca no seu ensaio o corpo que, nesse momento, só se olhava como o que servia para demarcar essencialismos e purismos terríveis, para voltar a colocá-lo como campo chave da luta de forças e discursos que continuamente disputam seu domínio. $\mathrm{O}$ inaudito questionamento nesses tempos em que poucos estavam acordados pedia atenção urgente ao ressurgir do mal elementar, e das potências primitivas reprimidas que nele revoltavam. Com as bandeiras da terra e do sangue ondeando-se no horizonte, e a apatia dos povos que entregavam sua angustia à nova imagem de adoração, Levinas lembra aqueles alertadores de incêndios que, como Benjamin e outros atentos às ruínas do tempo, nas suas passagens e viagens foram receptivos diante das camadas restantes e esquecidas a cada instante pelo discurso da história que se tenta impor sobre a multiplicidade. Ainda que no seu momento fossem pouco escutados, suas vozes inquietas ressoam entre nós e provocam ao pensar, ao fazer, ao escrever, à escuta dos vestígios no presente. 
Entre os campos de trabalho forçado, os seres humanos eram reduzidos a instrumentos de labor. Ali, o corpo desnaturalizado das vítimas devia apagar-se com a velocidade relâmpago dos massacres. Nessa experiência limite, cada um tentava salvar seus despojos como podia. O insaciável abismo dos fornos e as cicatrizes errantes se inserem nele e o estilhaçam; portar e suportar o desastre latente em cada poro demanda pensar outramente entre nós isso que somos: corpo; e reformular as representações que se fazem dele segundo os modelos obsoletos e cúmplices da denegação sofrida por séculos. Desejo de poder que se concentra sobre os corpos e, ao mesmo tempo, feroz recalque; jogo de boas consciências e puritanismos interessados no que a história mostrara às terríveis consequências. Essencialismos que acreditam em uma origem pura, esquecendo a heterogeneidade primordial que nos constitui, pois ela atenta contra a manipulação descarada que se pretende. Por aquilo que a homogeneização compacta e o estreitamento paulatino dos limites levariam ao afogamento progressivo. O sistema de domínio não se limita ao governo e às instituições, pois é obvio que pretende estender suas cabeças até as camadas mais íntimas da vida da cidadania, entre os espaços públicos e privados. A concepção ideológica que ostenta quer dar conta de tudo, nada poderia fugir da abertura do seu horizonte pressuposto de antemão. Não admite a diferença, pois qualquer oposição se toma como nociva e susceptível de purga ou extermínio.

Nesse sentido, não se poderia deixar de mencionar aqueles carrascos que desempenhavam o labor de cientistas, acadêmicos e doutores no regime nazista e a brutalidade das suas práticas, na missão obstinada e elaborada com detalhe de controle dos corpos até as mais íntimas fibras e em nome da mesma ciência, que nem sequer se envergonhava pelo servilismo ao domínio absoluto da vida e da morte; talvez nesses momentos extremos de confusão e mudança das aparências, a própria ciência, ao fim, deixava manifestada entre as sombras terríveis a outra face das suas luzes?

Não se pode esquecer a importância da medicina para um regime que pretendia perpetuar-se baseando sua ideologia na conservação das origens arianas e na respectiva discriminação de outras coletividades, ao serem qualificadas como inferiores. ${ }^{3}$ Através das ciências médicas pretendia-se que essas ideias contassem com a solidez da comprovação científica. Assim, por meio de muitos experimentos destinados a demonstrar a natureza da origem ariana, houve naturalização e banalização da violência na qual se pretende perpetuar os carrascos, isto permite ver como as tentativas de legitimação do genocídio foram mais longe, revelando as monstruosidades que o sonho da razão pode engendrar nos seus laboratórios, academias, campus
3. Além de todo um arsenal de propaganda e desprestígio, procurava-se o apoio em bases pseudocientíficas, em teorias como a "hierarquia das raças", formulada por pensadores europeus do século XIX, segundo a qual "alguns grupos teriam mais valor do que outros, em termos físicos, biológicos, culturais. Essa higienização étnica estava diretamente associada à teoria do darwinismo social". Ibidem, p. 271. 
4. Ibidem, p. 68.

5. De fato, desde 1943 o campo de Struthof Natzweiler dispôs de uma câmara de gás e um crematório financiado pelo Instituto Anatómico da Reichsuniversitat de Estrasburgo, a cargo do médico, capitão e membro da secção científica da SS, August Hirt, que deu instruções direitas e preparou pessoalmente o modo para que muitas vítimas fossem gaseadas, os números de registro tatuados na pele apagadas, partidos seus membros, decapitadas, saqueadas, queimada a cabeça à parte dos outros órgãos. Logo no fim da guerra, exceto um corpo dos 86 conseguiu ser identificado, o judeu Menahem Taffel. Essa marca terrível, quase ilegível, que se resistiu ao negacionismo dos carrascos, não cessa de alentar a memória. E testemunha mesmo sem testemunha, como os corpos estão expostos às mais terríveis violências, codificados, reduzidos violentamente a ser apenas uma cifra qualquer, algo menos que um zero. Cf. COURAND, Raymond, Un camp de la mort en France: Struthof Natzweiler, 2005.

\section{6. "Além das execuções} sistemáticas, a câmera de gás instalada em agosto de 1943 estava destinada para fornecer cadáveres para os experimentos praticados pelos médicos da SS no Campo de Struthof e na Universidade de Estrasburgo. Pelo pedido dos três médicos do campo, ela foi levantada onde, antes da invasão alemã, era um hotel. O quartel geral e o campo em que se tenha tornado dificulta imaginar que a montanha de Struthof antes da guerra fosse um campo esportivo reconhecido cujo hotel fundado em 1930 hospedava aos turistas e esquiadores que chegavam no inverno. Agora e campos, salas de vivissecção e mortificação: "Aqui como se pode comprovar, se encontra a mesa de disseção na qual o professor da Universidade de Estrasburgo realizava experimentos bacteriológicos"4. Boris Pahor lembra as vivissecções e experimentos bacteriológicos e como se controlava convenientemente a saúde dos prisioneiros e os tempos de morte, de acordo com as quantidades de gás que deviam receber segundo a sua utilidade experimental. Ele admite que preferia ficar diante do forno crematório do que em lugar de estar próximo dos azulejos da crueldade amarelenta da mesa de vivissecção.

Entre os modos de inferiorizarão do corpo, pode-se lembrar o Instituto Anatómico da Universidade de Estrasburgo (próximo a Struthof) e a coleção de esqueletos do doutor Hirt ${ }^{5}$, que reunia 86 dentre as 130 pessoas, que ordenou trasladar desde Auschwitz em $1943^{6}$. Todos aqueles corpos conservados em álcool de 55 graus foram despedaçados e queimados; de forma que o professor Hirt não teve a chance de realizar os seus modelos de hominídeos, nem de desossar os corpos para ficar, pelo menos, com os esqueletos. Operação que, talvez, tivesse a intenção perversa de servir de testemunho às gerações futuras, para que, ao ver os corpos embalsamados e os órgãos e a anatomia discriminada desses ossos, soubessem que em algum momento existiram "raças impuras" chamadas judia ou cigana, entre outras, cuja diferença já não havia que temer, pois já teriam sido exterminadas. No entanto, seus vestígios estariam confinados aos vidros dessa sórdida galeria. Aquelas "raças" consideradas inferiores eram destituídas de sua humanidade enquanto eram exibidas como os troféus de caça do conhecimento. Procurava-se anular a diferença de tal modo que fossem consideradas, para sempre, como outra entre as espécies extintas, exibidas nos museus do progresso. Assim, se alguns grupos de visitantes passassem por ali, poderiam, tranquilamente, fazer a pregunta impertinente que diz: Por que isso aconteceu? A resposta confiada do guia, que, com gesto de obviedade, diria: isto era necessário, não foi um massacre, mas um logro inestimável da nossa espécie e seu douto intelecto.

Há poderes e interesses terríveis que se inscrevem nessa exposição irremediável dos corpos. Esses mesmos corpos submetidos a tratos que não dá para qualificar de inconcebíveis, pois foram suplícios concebidos sim, e até metodicamente, com planos e milhões de listas em mãos e registros dos deportados nessa rede desenfreada de corpos semimortos e de doenças que se transportavam pelas vias ferroviárias que conectavam as diferentes frentes nazifascistas.

$\mathrm{E}$ tantos outros instrumentos fabricados especialmente para internar-se nas imediações da agonia das entranhas abertas para, depois, eficaz e eficientemente, devolvê-las ao nada. 
Assim, Boris Pahor se pergunta pelo perfil psicológico de quem inventou aquelas tesouras (instrumentos frios e enormes aptos para arrastrar os corpos quase cadavéricos até as duchas e logo ser jogados dentro dos fornos). Lembrando os planos radicais de limpeza e higienização que se propôs o regime, e diante das torturas alongadas, as inacabadas marchas da morte, o sofrimento inútil, o azote constante dos carrascos, o desamparo e as marcas do genocídio entre os corpos jogados no chão, o sobrevivente reflete:

Era uma forma de agonia prolongada; assim como era uma agonia prolongada o enfraquecimento sem fim dos corpos famintos. Ao que parece, o alemão precisa do ritmo de um lento, refreado sadismo com que torturar a si mesmo na expiação dos antigos crimes da sua raça. Nesta funérea loucura, os desvios sexuais tinham um papel bastante importante, considerando o zelo com que o regime se dedicava a esterilizar e castrar. $^{7}$

A sintomatologia desses gestos, entre outras infinidades de questões, talvez mostre como, na coleção pretendida pelo doutor Hirt, as fragilidades desses corpos expostos a tais condições expõem a impureza, a inevitável heterogeneidade; a infinita contaminação, mas também o medo patético, o inegavelmente visceral, a náusea traduzida em desejo de domínio e rancor diante da vida e da morte, apartadas e conservadas entre as vitrines das instituições científicas e educativas, para que servissem de prova incontestável do poderio. São esses cadáveres que ainda servem de mordaça às ignominias do presente, por isso não se podem esquecer seus cacos. Foram e são os restos sinistros do que as ciências, a medicina e a biologia, não podem desfazer-se, pois eles portam as marcas do desastre e daí solicitarem infinitamente a não aprisionar a ninguém nas determinações biológicas.

Memórias abismais dos corpos cinzentos, das que não apenas a medicina precisa lembrar-se, mas também as ciências experimentais da atualidade, quando tudo corre o risco de reduzir-se à competência; uma marcha acelerada, teste e desenvolvimento instrumental, genocida salubridade. Onde os corpos de todos, não só dos humanos, mas, sobretudo, dos viventes não humanos, e, inclusive, das máquinas e das coisas, se tornam apenas os meios de um sistema de progresso, expansão e extermínio, técnico e racionalmente concebido, que não conhece fins distintos de si mesmo. E não tem desculpas aquela retórica baseada no instinto de conservação do que procura perpetuar-se. Processo de devastação dos corpos levado à cabo em nome das pretenciosas ambições das quais as ciências não podem simplesmente desaperceber-se. Há a seguinte inscrição em honra daqueles que foram assassinados pelo doutor Hirt, na placa comemorativa que data de 11 de dezembro de 2005: sei pelos livros que li, que ao professor Hirt foram entregues oitenta corpos, homens e mulheres, que o comandante do campo Kramer tinha matado com o gás entre estes ladrilhos brancos depois de recebê-los de Auschwitz. O professor Hirt guardava-os com todo o cuidado no Instituto Anatômico de Estrasburgo para estudar, neles, as particularidades somáticas do homem “inferior"”. PAHOR, Boris. Necrópole, 2013, p. 250.

7. Ibidem, p. 236. 
8. Em memória das 86 vítimas judaicas assassinadas em 1943 em Struthof por August Hirt, professor da Reichsuniversität nazista de Estrasburgo. Seus restos mortais encontramse no cemitério israelita de Cronenbourg. A faculdade de medicina francesa de Estrasburgo foi anexada ao Clermont-Ferrand. Lembre-los de modo que a medicina nunca mais seja pervertida.
En mémoire des 86 victimes juives assassinées en 1943 an Struthof par August Hirt, professeur à la Reichsuniversität nazie de Strasbourg. Leurs déponilles reposent au cimetière israélite de Cronenbourg. La Faculté de Médicine française de Strasbourg annexé était repliée à Clermont-Ferrand. Souvenez-vous d'elles pour que jamais plus la médecine ne soit dévoyée. ${ }^{8}$

Porém, nem centos de placas adiantam para apagar os gritos e as memórias das milhões de catástrofes que, em nome da cega auto conservação de uma espécie, e sob a cumplicidade de uma medicina descarrilhada, para tomar o título do livro do doutor Blaha. A carnificina não para entre as instalações legalmente invioláveis dos laboratórios de pesquisa e, das fábricas de processamento na carreira pela conservação, entre outros lugares, que sendo muito próximos do sem saída dos campos, ainda que, com desmedidas diferenças, continuam violentando cruelmente tantos corpos viventes, não apenas humanos, mas também animais, sob o auspício do Estado. A literatura de testemunho em Boris Pahor deixa ressoar o transbordamento violento dos limites, as vozes dessas outras vítimas da destruição, os animais que sofrem, mas, sobretudo, para referir-se nesse traço ao mesmo tempo àqueles seres humanos que são animalizados violentamente pela exclusão, o racismo, o totalitarismo, o poder soberano.

Várias imagens que entrecruzam o sofrimento animal às condições inumanas dos prisioneiros nos campos de concentração vêm ao encontro da testemunha quando se aventura entre as sombras de Struthof. Assim, poderia lembrar-se aquele momento em que as sobrevivências do campo levam, entre montagens e sequências de imagens, que talvez só uma câmera poderia registrar, lá e aqui, quando aquilo a que se submetia aos prisioneiros não está nem muito longe nem muito próximo das fábricas de produção de alimentos baseados em animais. O retorno a Struthof é enxergado por Pahor como a volta do homem adulto ao local onde foi criança, quando a realidade era olhada segundo a perspectiva do pequeno, mas também do extremamente vulnerável e nu, como um animal famélico que se consome impotente no seu cativeiro. A propósito dessa animalização dos prisioneiros levada pelos nazistas, em Necrópole é possível perceber algumas marcas textuais que perpassam o corpo da escrita. Ali se podem encontrar, entre as massas de cativos, seres secos reduzidos às condições últimas e que foram destituídos do estatuto de humanos para virar zebras, bípedes, piolhos, ratos, pássaros famintos, aves magras, para seres despossuídos cruelmente do seu nome, expostos ao abismal na fragilidade das suas existências, em nome da bestialidade soberba dos amos. O que talvez, por outro lado, se poderia relacionar, em certas questões com a literatura de testemunho que 
oferecem entre outros, Coetzee, em textos como $A$ vida dos animais ${ }^{9}$, onde a partir dos depoimentos, os diálogos das personagens e o conflito do drama de milhões de viventes, não apenas 9. COETZEE, J. M. $A$ vida dos animais, 2002.

homens, nem só humanos, mas também outros animais, se entretecem narrativas testemunhais dessa outra dor intraduzível, literatura exposta à nudez da ferida, ao olhar estranho e íntimo, in-familiar das alteridades, desses outros animais, destinerrância e heterogeneidade indissociáveis do testemunho, que mesmo na sua singularidade irredutível deixa ressoar mais de um desastre. Assim, entre essas latências se denunciam as práticas sacrificiais que ainda se repetem, em nome dos santos da ciência, do progresso e da segurança.

O abjeto relacionado ao visceral, ao abismal corporal, não deixa de lembrar os animais. Estranhamente a literatura, essa estranha instituição, deixa em algumas ocasiões passar entre suas pegadas os rastros Unheimlich desse outro olhar que gera comoção nas entranhas, se deixa transpassar entre margens sinistras que interferem e tornam indefinidamente instável qualquer limite entre dentro e fora. No tremor o corpo exposto tão desmedidamente à abjeção dos campos procura aferrar-se a algo que lhe permita não desintegrar-se na densidade das sombras e do silêncio. Esse drama vivido pelo corpo na sua luta entre a esperança de sobrevivência e a desesperança de estar submetido ao ritmo frenético e esmagador da guerra perpassa a escrita, sendo encarnada pelo testemunho em diferentes momentos, nos quais se presta escuta ao silencioso réquiem dos ossos quebrados pelas infernais jornadas. A narração implica intensamente cada fibra, as sensações lembradas, a descrição do acontecido, as imagens se caracterizam pelo seu caráter orgânico, celular; na materialidade das suas palavras a testemunha tenta explorar as camadas entre as sombras, ainda que isto seja o impossível mesmo, e sempre reste em falta, pois a boca não suporta o grito mudo que a excede, se tenta dar conta do abismo de abjeção pelo que atravessaram incontáveis corpos entregues ao alento da montanha. O drama do corpo por resistir, ainda com suas últimas reservas, ainda com o cheiro da morte no nariz, enquanto o medo por um final pressentido beijava as entranhas, se inscreve no testemunho que recolhe e se expõe aos restos de cada tecido incinerado, assim, o testemunho do corpo mesmo esmagado, $\mathrm{nu}$, cheio de doenças, fome ou frio, batido incessantemente, impregnado do cheiro do extermínio, embriagado pela neblina anestesiante, tenta renascer a partir da fragilidade das cinzas.

O labor de enfermeiro (logo que um médico norueguês, também prisioneiro político, lhe deixasse ser seu ajudante e tradutor) quiçá contribuiu para que Pahor tivesse outra apreciação dessa implacável exposição dos corpos que se testemunha no relato, pois ele esteve diretamente envolvido com aqueles 
10. PAHOR, Boris, Necrópole, 2013, p. 37.

11. DERRIDA, Jacques.

Séminaire La peine de mort, 2012, p. 23.

12. Ibidem, p. 24. corpos em sofrimento, inclusive foi vítima da tuberculose, o que é inevitável devido ao contato entre os doentes. Uma doença podia ser letal ou não era nada diante de ameaças piores. Essa vulnerabilidade entre os corpos lembra não apenas o letal que podiam ser as doenças, mas que a doença poderia ser até o contágio de um mal invisível, que não se apalpava ainda que estivesse em todas as partes. No Lager, os perigos se relativizam até que o absurdo se torna o rotineiro, a cotidianidade do dia a dia, nessas idas e vindas desse mar de gente atormentada; a possibilidade de acabar com um disparo no rosto se torna tão natural e comum como respirar. Entre os doentes, Pahor se lembra daqueles que o regime afastava em quarentena, em uma espécie de ilha aparte dentro do campo, como se, ciumentamente, se tratasse de impedir à morte roubar essas vítimas cujo destino foi decretado nas duchas. "A barraca era uma moradia de madeira numa ilha destinada aos leprosos desde a que tenha partido em silêncio e para sempre o último buque humano"10.

A paixão pela salubridade dos nazistas chama a atenção. O vocabulário da limpeza parecia indissociável do aniquilamento em cada guerra librada contra outros. Havia uma necessidade de manter o comando sobre o processo de fabricação da morte. Essa desesperada tanato-ditadura exercida pela burocracia do regime nazista para ter e administrar sobre a vida e a morte, para declarar a pena de morte quando era de sua conveniência, no esmero para fazer disso sua propriedade, ou aquilo que é considerado como o "próprio do homem", fazer acreditar nisso e fazer com que isso fosse acreditado pelos outros, mesmo sob pena de morte por não ser obedecido.

Jacques Derrida abre seu seminário sobre a pena de morte em 1999 e 2000 no seu longo trabalho da Responsabilidade na Hautes Etudes, com estas frases: “Que répondre à quelqu'un qui viendrait vous dire, à l'aube: "Vous savez, la peine de mort est le propre de l'home"'"11. Teologia política, religião da pena de morte, da pena de morte como religião ${ }^{12}$ que são indissociáveis dessa pretensão de considerar como natural a excepcionalidade da capacidade de impor a pena de morte, como o próprio do homem e sobre o que se fundam os estados e as estruturas do direito.

Pensamento que solicita escuta, pelas noites e pelos dias das nossas vigias e os nossos sonhos, até o infinito despontar da Alba. E onde se coloca um desses "próprios do homem" sobre os que se levantam e querem naturalizar o seu controle temível sobre a morte e sobre a vida daqueles que se acham com o poder de exterminar os outros. Não podiam ser as epidemias, nem as doenças que levaram os prisioneiros aos sepulcros, o Estado nazista brigava até com essas forças para tomar completo domínio do único que ainda escapava de suas mãos: 
a morte do outro. Até a última etapa, o carrasco acompanha o processo de aniquilação, como a bruxa que engorda sistematicamente a Hamsel e Gretel para devorá-los. Assim a voracidade de cadáveres do sistema nazista tenta encher de humilhações suas vítimas para depois roubar sua morte, em uma tentativa obstinada por deter a fuga da morte, para dominá-la e obter o poder absoluto, até o obsceno. Pois submeter a essa alteridade radical da finitude seria a maior prova de poderio. "O corpo é nossa angústia posta ao nu"13. Resulta um evento limite. Marcas de memória traumática percorrem sua textura. Para Jean-Luc Nancy, o corpo não deixa de ser o produto mais tardio, o mais longamente decantado, refinado, desmontado e novamente montado da nossa velha cultura ${ }^{14}$ :

\begin{abstract}
Somos corpo e os corpos resultam propriamente outros. $\mathrm{O}$ que quer dizer que não há dado, nem a origem resulta purismo essencial, mas heterogeneidade inesgotável. Os corpos são primeiramente e sempre outros - ao igual que os outros são primeiramente e sempre corpos. (...) Outro é um corpo porque só um corpo é outro. (...) Porque é outro - e a alteridade consiste no ser - tal, no sem fim do ser tal e tal e tal desse corpo, exposto até as extremidades. O corpus inesgotável dos traços de um corpo. ${ }^{15}$
\end{abstract}

Traços que não deixam de gerar efeitos, perturbações, alteridades diante das quais o escritor não fica indiferente. Pode se ver em Boris Pahor, de forma notável, como sua preocupação se dirige menos ao terror das câmeras que à sorte adversa das vítimas nelas destruídas. O que os rumores dizem e a imaginação supõe se vem abaixo diante do contato com a finitude entre os corpos da dor. Ao encontrar um anúncio lembra que:

Joseph Kramer, no processo, contou que as mulheres tinham de entrar aqui dentro completamente nuas; aí Hirt, através de um cano, introduzia no local os sais voláteis e ficava apreciando o espetáculo por uma janelinha. Seu testemunho está agora pendurado na parede, à esquerda da entrada. Isso acontecia em 1943. No ano seguinte, quando eu estava aqui, o local era usado (pelo menos na medida do que eu pude constatar) principalmente com os ciganos. Vi-os no quinto pavilhão, quando cheguei ao Revier como intérprete de Leif. Antes daquela época, a câmara de gás só adentrara o território da minha fantasia como imagem vaga e indefinida. Na correnteza e nos meandros do rio dos famintos mantivera-se nos bastidores, muito mais distante que a chaminé e a sua fumaça. ${ }^{16}$

Assim, Necrópole deixa tremer nessa ferida terrível dos centros de cobaias humanas, onde os alaridos do corpo aberto sem anestesia não podem vir a intrometer-se na empresa de redução e reprodução em massa homogênea do corpo do Terceiro
13. NANCY, Jean-Luc, Corpus, 2003, p. 12.

14. Ibidem, p. 11.

15. Ibidem, p. 26.

16. PAHOR, Boris, Necrópole, 2013, p. 250-251. 
17. Ibidem, p. 253.

18. Que foi o médico principal em Auschwitz e cuja tese de doutorado na universidade foi intitulada "Investigação morfológica Racial sobre a seção inferior do maxilar de quatro grupos raciais", e que naturalmente correspondia com os fines nazistas. Seus experimentos com genética e eugenia de gêmeos, a memória dessas perversões, precisam não ser esquecidas, sobretudo hoje em que ditas ciências têm sofrido mutações e desenvolvimentos evidentes. Não se pode continuar na visão ingênua que se quer previr do abjeto e agir de acordo ao sintomático positivismo, na articulação com fins perversos entre o conhecimento médico e a ideologia política. As práticas que engendram e que solicitam estar atentos no corpo a essa relação que a diário nos afeita de múltiplas formas no cotidiano, e que perpassa os saberes com que as ciências entretecem em corpo a corpo e a mais de um o seu corpo e corpus de estudo. Assim entre políticas, éticas e estéticas ao limite abissal é necessário escutar essas escrituras do corpo nos diversos espaços do que acontece, na vida, na morte, nas sobrevivências e nas latências do desastre, entre as coreografias e rastros do corpo, esses signos errantes que não se acabam de querer manipular.

19. PAHOR, Boris, Necrópole, 2013, p. 226-227.

20. REYES-MATE, Memórias de Auschwitz - atualidade e política, 2005, p. 36.
Reich. Ao tempo que lembra às ciências da atualidade, o fato de que não podem desentender-se de seus limites na desenfreada procura da eficácia e da eficiência. "Nunca quis saber onde a câmara se encontrava; procurava cuidar, antes, dos jovens ciganos a quem o professor administrara uma dose mais fraca, a fim de avaliar melhor a eficácia do novo gás"17.

Nos campos, o processamento e a reciclagem dos corpos não conheceram limites. Disso exatamente tratava de apoderar-se e destroçar sem piedade esse limite que é o corpo, para demostrar que nada poderia fugir das mãos e tudo de antemão devia ser submetido, por direito natural e divino. Struthof não foi o único campo que conheceu ditas ações, também estão as experiências pseudo-médicas e de desprendimento de tecidos, de ossos, experimentação de resistência a condições insuportáveis, doenças, vírus e armas biológicas, entre outros artefatos que se incrustavam no corpo, desenvolvimentos genéticos etc, sobretudo em campos como Ravensbruck e Dachau. Os Mengele ${ }^{18}$, os Hirt, os Gepphard, entre outros, que com suas batas brancas cobertas de sangue e sal cianídrica passaram à história como "anjos de morte", não podem ser esquecidos nesses momentos de emergência em que a humanidade confiada nos delírios de conhecer e tomar domínio de todo se topa de repente com a oz e o estetoscópio do nada.

O doutor Blaha conta que, em Dachau, peles humanas eram penduradas como panos a secar. Eram usadas para se obter um couro muito fino, perfeito para calças de montar, pastas e carteiras, pantufas macias e encadernações de livros. Não era aconselhável, brinca o doutor Blaha, ter pele bonita. O livro dele é uma revelação com mais de trezentas páginas. Achei que sabia muita coisa acerca dos campos, mas diante de testemunhos como o dele, sinto-me realmente um novato. Volto a repetir: quando estava lá, não fazia a menor questão de penetrar os mistérios do Lager. Evitava-os como se fossem um invisível raio letal. ${ }^{19}$

Línguas e corpos e qualquer possibilidade de articulação entre ambas as instâncias devia ser afogada. Tanto os corpos como o corpus dos povos e das culturas, que se discriminavam na sua diferença deviam ser absolutamente extinguidos.

Sin soporte físico, debía desaparecer igualmente la significación cultural de ese pueblo y su contribución a la historia de la humanidad. Se trataba de producir un crimen de tal magnitud que, aunque alguien escapara de la cámara de gas y lo contara fuera, nadie le creería por la desmesura del acontecimiento. $\mathrm{Y}$, aunque le creyeran, tratarían de olvidarlo porque tenerlo presente era vivir con un fardo insoportable. $^{20}$ 
Ainda que o segredo manifesto reste esquartejado, ou mesmo ausente do corpo destroçado no Lager despertando-nos ao limite do real, não há como se imunizar, é o abjeto ${ }^{21}$ que relampagueia brutalmente na noite da história, marcando mais e menos de uma cripta entre nós. Os múltiplos corpos em ruína que transbordam a língua de Pahor impregnam nossas leituras e escritas transcorporais, as retorcem e nos põem em contato iniludível e impossível dos estigmas da catástrofe e das violências cernidas sobre eles.

Como pensar outramente o corpo, como evento e desastre iniludíveis? Não há como não se empapar com o "fedor da decomposição, a podridão e a diarreia dentro do qual trabalhávamos e dormíamos, e com todo o seu ser se rebela contra a piedade por uma raça que tanto envenenou e infectou a Europa e o mundo inteiro"22. Entre as dobras e desdobras dos signos e das vozes disseminadas na pele arrugada em múltiplos tempos sem idade fixa, o peregrino entre as sombras talvez permita evocar a outro que na (in)citação da dor da noite e traça, o alento entrecortado destas palavras de Zé Celso Martinez Corrêa: "E a experiência da sobrevivência na noite desses anos, sua memória, está gravada no corpo..."23.

\section{Referências}

ADORNO, Theodor; HORKHEIMER, Marc. Dialéctica del iluminismo. Madrid: Akal, 1997.

BENJAMIN, Walter. Discursos interrumpidos. Madrid: Taurus, 2000.

COURAND, Raymond. Un camp de la mort en France: Struthof Natzweiler. Estrasburgo: Ed. Hirlé, 2005.

COETZEE, J. M. A vida dos animais. São Paulo: Companhia das letras, 2002.

DERRIDA, Jacques. Séminaire La peine de mort. Vol. I (1999 2000). Paris: Galilée, 2012.

KRISTEVA, Julia, Powers of Horror: An essay on Abjection. New York: Columbia University Press, 1982.

LEVINAS, Emmanuel. Descobrindo a existência com Husserl e Heidegger. Lisboa: Editora Piaget, 1997.

\section{Carnets de captivité suivi de Écrits sur la captivité et}

Notes philosophiques diverses. Éditions Grasset \& Fasquelle, IMEC Editeur, 2009.
21. Nos estudos de Kristeva e também nos de Márcio Seligmann-Silva, entre outras e outros, pode-se apreciar esse reconhecimento do abjeto que chama a pensar nesta questão vital entre as artes e as literaturas do testemunho. Cf. KRISTEVA, Julia, Powers of Horror: An essay on Abjection, 1982. SELIGMANNSILVA, Márcio, História, memória, literatura: $O$ testemunho na era das catástrofes, 2008.

22. PAHOR, Boris, Necrópole, 2013 p. 260.

23. PENNA, João Camilo, Escritas da sobrevivência, 2013, p. 7. 
Tradução de Ricardo Ibarlucía. Buenos Aires: FCE, 2001.

MATE, Reyes. Memórias de Auschwitz - atualidade e politica. São Leopoldo: Nova Harmonia, 2005.

NANCY, Jean Luc. Corpus. Madrid: Ed. Arena Libros, 2003. . "La existencia exiliada. Archipiélago". Cuadernos de la cultura, n. 26, 1996.

NATZWEILER-STRUTHOF. Camp Survivors. Hephaestus books.

PAHOR, Boris. Necrópole. Tradução de Mario Fondelli. Rio de Janeiro: Bertrand Brasil, 2013.

PENNA, João Camilo. Escritas da sobrevivência. Rio de Janeiro: 7 Letras, 2013.

SELIGMANN-SILVA, Márcio. História, memória, literatura: O testemunho na era das catástrofes. Ed. Unicamp, 2003.

STIVELMANN, Michael \& Raquel. A marca dos genocídios. Rio de Janeiro: Imago Ed, 2001. 